До Хонг Тханг

(Do Hong Thang) expert

Vietnam Trade Union University г. Ханой, Социалистическая Республика Вьетнам

DOI $10.21661 / r-471867$

\title{
REVIEW OF LIVING CONDITION ON CAMPUS OF COLLEGE STUDENTS IN VIETNAM
}

Аннотация: жизнь студентов на кампусе всегда была проблемой не только для студентов, но и многих педагогов. Возникающий консенсус среди исследователей показывает, что помимо многих недостатков могут испытывать студенты. Потенциильные выгоды студенты могут получить от жизни в среде университетского городка. Опросник проводился по студентам из 8 университетских городков в Ханое. Цель исследования - изучить, как вьетнамские студенты используют университетский городок университетов в Ханое с точки зрения ученых, а также повышения квалификации межличностных навыков. Основываясь на полученных результатах, выяснилось, что большинство студентов на кампусе не могут полностью использовать эту среду. Даны рекомендачии с тем, чтобы помочь студентам лучше понять все преимущества жизни в кампусе, которые позволяют им подготовиться к дальнейшей карьере и самостоятельной жизни.

Ключевые слова: кампус, студенты, состояние жизни, институт.

Abstract: on-campus students' life has always been a concerning issue for not only students but also many educators. The emerging consensus among researchers indicate that apart from many disadvantages students are likely to experience, there are potential benefits they can gain from living in a campus environment. A questionnaire-based survey was carried out on students from 8 university campuses in Hanoi. The research's goal is to explore how Vietnamese students take advantage of universities campus in Hanoi in term of academics as well as interpersonal skill 
enhancement. Based on the findings, it has been revealed that most on-campus students can not make full use of this environment. Therefore, recommendations were given with the hope to help students better perceive all benefits from campus life, which enable them to prepare for later career and an independent life.

Keywords: campus, college students, living condition, university.

\section{Introduction}

One of the most concerning issues facing thousands of Vietnamese students who are living far away from home for college these days is to find a suitable accommodation. There is, in fact, an annually overloaded demand for rooms available on campus. According to Department of political education and students' work, Ministry of education and training (2016), only 30\% to $40 \%$ of demand for dormitory is satisfied by universities' administration nationwide. A lot of research has been conducted to find out benefits offered by campus to students. Living on campus has been found to have a significant positive effect on students' persistence, improving independent life kills and social skills $[2,10]$ Hence, the scope of this study is to explore how Vietnamese students make use of this living learning environment in terms of academic and non-academic enhancement.

\section{Material and methods}

A three-part questionnaire was developed to collect information from students. The very first part is to explore the reason students like or dislike the campus life. Meanwhile, the next three questions examine how on-campus students take advantage of available material sources and their partners to foster their academic skills. The last part of the questionnaire comprises three questions to discover how campus life exerts influence on students' interpersonal skills. Given the fact that not all respondents could fully understand the questionnaire in English, a bilingual version was designed so that the survey could be done successfully. The questionnaire was trialed on a group of on-campus students before being executed.

The subject of the study consists of 468 random-selected college students of all ages over 18. The survey was conducted on 8 universities campus in Hanoi in 
October 2017. Each participant was given a questionnaire paper and asked to indicate his honest answers. After 30 minutes, all of the handouts were completed and returned for the further analysis.

Results and discussion. Reason for campus life

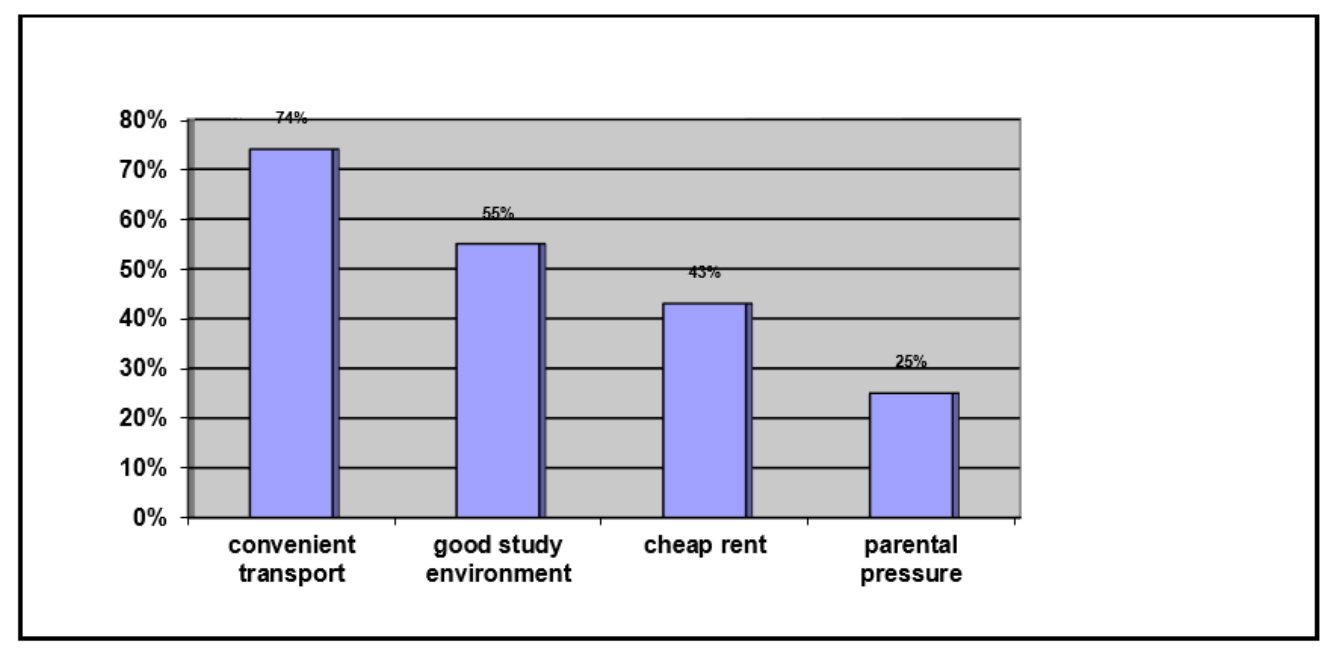

Figure 1. Reason for campus life

The result of the research survey shows that there are considerably different reasons why students choose campus life. As can be seen in figure 1, an overwhelming majority of respondents (74\%) declare that convenience in transport is their top consideration before moving to campus. It can be understood that some unexpected factors affecting students' class attendance such as bad weather or traffic jams can be remarkably minimized thanks to the relatively short distance from the dormitory to school. Moreover, the worries regarding transport expenses might be eliminated, which saves them a large amount of living expenses. Meanwhile, 55\% of participants see campus as a good learning environment. In comparison with their counterparts as commuters, on-campus students are devoted to academic pursuits, not being distracted by family's business and [6;9]. Obviously, Vietnamese students are deeply aware of benefits of campus environment while attending college. Thus, with the privileges of living in dormitory, the ways they make use of this living learning environment to support their academic and non academic skills will be discussed below.

Academic skills 
Campus can assist students' study by providing them available material sources, to practice language, and exchange study experience as well. Further details about students' response towards all the above opportunities will be obtained in this following part.

\section{Frequency of library use}

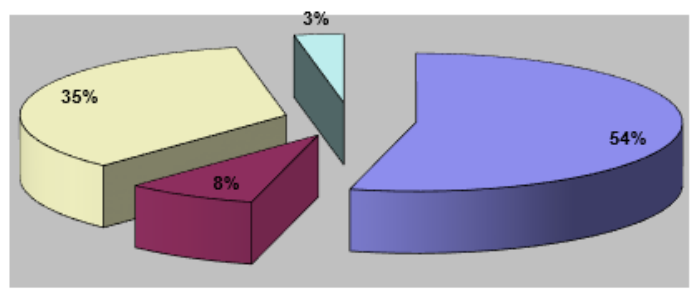

口Sometimes
口Often
$\square$ Never
$\square$ Always

Figure 2. Frequency of library use

As shown in figure 2, the library is not frequently visited by over a half of respondents. Meanwhile, there is more than one in three students who doesn't use library. Additionally, only a minority of participants (8\%) spend much of their time discovering this literature resource. The statistics proves that despite the relatively easy- access to the available material, these students do not get themselves involved in utilizing this treasure. Some students did conclude that if the college did not have a library, faculty and students might feel worry but since the library is always there, it is easily ignored [4, p. 72]. However, according to some respondents, this fact can be due to library's shortcomings itself namely shortage of materials and time restriction posed. Therefore, a suggested solution is that improving library quality should be taken into consideration so that the library can become a frequently visit sites by students since it could assist academic help by delivering units of material, scientific learning inputs [3, p. 35].

\section{Language practice}

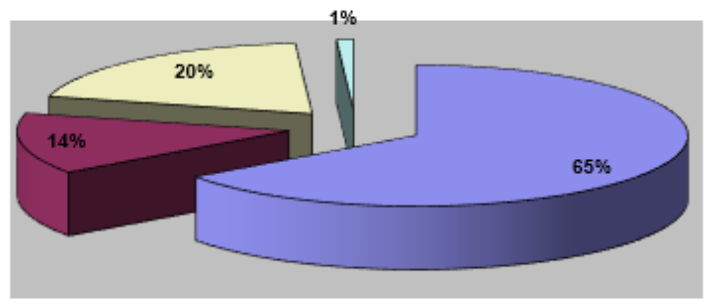

口Sometimes

口Often

口Never

口Always 
Figure 3. Frequency of language practice

Differ from foreign language learning method in high schools, college students can easily access to variety of effective learning ways, among which is team work. In fact, college students on campus have better chance of exchanging their accumulated language knowledge with other foreign language learners sharing the campus life through group working. Nevertheless, as can be seen from figure 3, $65 \%$ of students reported to «sometimes» practice language with their on-campus partners, while a sizable number $(20 \%)$ reports a total procrastination of language practice. Noticeably, only $14 \%$ of them prefer to employ practice method with others and the highest frequency of language practice («always») accounts for negligible number (1\%). This disproportion can be traced to the differences in timetable and linguistic ability constituting formidable barrier among on-campus students. A great number of viewpoints, therefore, are favor of independent learning styles. Nonetheless, according to [8;9] «small groups are probably the most effective way for communicative language work'. Therefore, it is suggested that those students should be more engaged in creating communicative linguistic environment «as undergraduates develop linguistic skills, they hone the quality of their thinking, becoming intellectually and socially empowered' [2, p. 73].

Study experience sharing

In terms of study experience exchange, a dominant number of respondents $(75 \%)$ share the same opinion of academic experience gaining from others on campus. Furthermore, material sharing is familiar with $48 \%$ of students involved. This statistic is well supported by the view of Boyer [2], campus is a place for students to seek a community of learning that permits an exchange of ideas and experience across generation. According to the data, on campus students are willing to pass valuable academic experience and materials down to other partners. As a result, they appear to reflect their own and other's perspective, expand their viewpoint to find out self-preferred learning style as well as saving money thanks to material exchange such as books, CDs within their mutual supports. 


\section{Interpersonal skills}

Campus is not only a learning environment but also small societies where students can reach out to each other; enhance personal skills in spirits of friendship and community sharing.

\section{Relationship maintenance}

Getting along with other roommate plays a vital role for on-campus students' life.

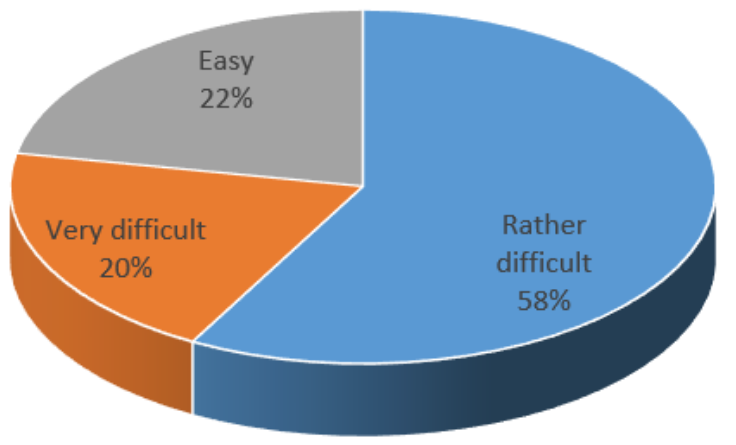

Figure 4. Relationship maintenance

As illustrated in figure 4, a surprising large number of responds (78\%) reveal that they face some challenges to some extent, whereas only $22 \%$ report that creating harmonious relationship is not a matter of great concern. This can be result of differences between background and characteristics among students on campus as they come from different parts of the whole country. The findings suggest that there still exists an invisible barrier in students' community preventing them from being in a good term with each other. This collected data is contrary to previous research asserting that living on campus was directly associated with significantly high level of openness to diversity through their interaction with peers [9]. As a result, it is essential for respondents to find out common interests, seeking a climate in which friendship cooperation can be strengthened.

\section{Problem-solving}

On campus, students are likely to encounter great deal of psychological and financial worry. Regarding problem solving, a vast majority of respondents (70\%) seek help from others living off-campus such as their parents, old friends, or 
lovers. In contrast, turning to «roommates' for trouble sharing in presented by only 30\%. Nonetheless, one finding [1] indicated that emotional disclosure (e.g. one's deepest feeling, one's worse fear) is easily recognized by roommates, this perception leads to feeling understood, validated, and cared for. The difficulties in creating a harmonious environment among participants as mentioned above may be the reason for students' lack of intimacy to confide troubles to their roommates on campus.

\section{Activity participation}

Campus often play host to live performances like music and film screening as well as talk shows of famous people delivering speech about most concerning issues among students. Living in this environment, students are likely to take advantage over their off-campus counterparts in terms of time and distance to take part in campus's activities.
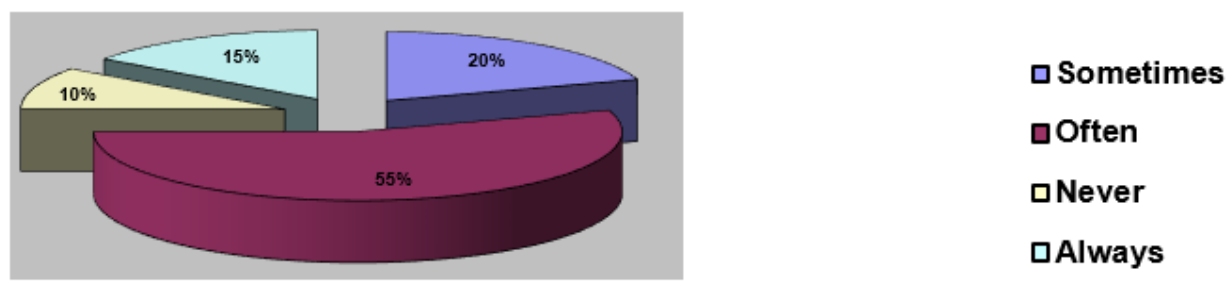

Figure 5: Activity participation

Figure 5 describes that over half of respondents enjoys those activities with high frequency. Moreover, $15 \%$ of them have full attendance while only small proportion (10\%) refuses all extracurricular activities campus held. The emerging consensus among researcher reveals a positive correlation between students and oncampus activity participation. The result from those studies shows that students' involvement in extracurricular activities reaps potential benefits such as helping them bridge the world inside and outside dormitory, develop new skills, social experience and make new friends [5].

\section{Conclusion}

In summary, based on the findings, it can be concluded that most on-campus students can not make full use of this environment. Thus, in the near future, they should 
notice further about the significance of group or pair work along with fostering the frequency of library use. In addition, the spirit of cooperativeness and solidarity through extracurricular are suggested to be taken into great consideration. Moreover, those students also express their wish to have easier internet to increase their educational achievements, and social skills. Hopefully, universities in Vietnam can consider students' recommendations, which will further facilitate their study and social life.

\section{References}

1. Aron A. Handbook of closeness and intimacy / A. Aron, D.J. Mashek. - Lawrence Erlbaum Publisher, 2008.

2. Boyer L.E. College - The undergraduate experience in America. - New York: Harper \& Row publishing group, 2008.

3. Dugan D.E. Action plan for outcomes assessment in your library / D.E. Dugan, P. Hermon. - ALA Edition Publishing, 2002.

4. Ellis D. Becoming a master student. - Boston: Houghton Mifflin Company publisher, Inc., 2010.

5. Matthew J. Mayhew Bowman. How college affects students / J.Mayhew Matthew, N. Alyssa. - Jossey - Bass publisher, 2016

6. Kud D.G. Disengaged commuter students: fact of fiction / D.G. Kud, M.R. Gonyea, M. Palmer. Indian university press, 2004.

7. Jessica Paola T.P. Unveiling students' perception \& attitudes. - Bogota, 2016.

8. Nunam D. The learner-centered curriculum. - Cambridge university press, 2005.

9. Pike G.R. Differential effects on-and-off campus living arrangements on students' openness to diversity http://publications.naspa.org/naspajournal/vol39/iss4/art6/

10. Alexander A. What matters in college: Four critical years revisited. Jossey Bass publisher, 2014. 